\title{
The anticancer immune response of anti-PD-1/PD-L1 and the genetic determinants of response to anti-PD-1/PD-L1 antibodies in cancer patients
}

\author{
Xinbing Sui ${ }^{1,2,3, *}$, Junhong $\mathrm{Ma}^{5, *}$, Weidong Han ${ }^{1,2}$, Xian Wang ${ }^{1,2}$, Yong Fang ${ }^{1,2}$, Da \\ $\mathbf{L i}^{1}$, Hongming Pan ${ }^{1,2,3}$ and Li Zhang ${ }^{3,4}$ \\ ${ }^{1}$ Department of Medical Oncology, Sir Run Run Shaw Hospital, Zhejiang University, Hangzhou, China \\ ${ }^{2}$ Biomedical Research Center and Key Laboratory of Biotherapy of Zhejiang Province, Hangzhou, China \\ ${ }^{3}$ Department of Immunology, University of Toronto, Toronto, ON, Canada \\ ${ }^{4}$ Transplantation Institute and Toronto General Research Institute, University Health Network, Toronto, Canada \\ ${ }^{5}$ Department of Gastrointestinal Surgery, Nankai Hospital, Nankai District, Tianjin, China \\ * These authors have contributed equally to this work \\ Correspondence to: Hongming Pan, email: drpanhm@aliyun.com
}

Li Zhang, email: lizhang@uhnres.utoronto.ca

Keywords: PD-1, PD-L1, cancer, checkpoint inhibitor, immunotherapy

Received: May 26, $2015 \quad$ Accepted: July 08, $2015 \quad$ Published: August 05, 2015

This is an open-access article distributed under the terms of the Creative Commons Attribution License, which permits unrestricted use, distribution, and reproduction in any medium, provided the original author and source are credited.

\section{ABSTRACT}

The programmed death-1 (PD-1), a coinhibitory receptor expressed on activated $T$ cells and $B$ cells, is demonstrated to induce an immune-mediated response and play a critical role in tumor initiation and development. The cancer patients harboring PD-1 or PD ligand 1 (PD-L1) protein expression have often a poor prognosis and clinical outcome. Currently, targeting PD-1 pathway as a potential new anticancer strategy is attracting more and more attention in cancer treatment. Several monoclonal antibodies against PD-1 or PD-L1 have been reported to enhance anticancer immune responses and induce tumor cell death. Nonetheless, the precise molecular mechanisms by which PD-1 affects various cancers remain elusive. Moreover, this therapy is not effective for all the cancer patients and only a fraction of patients respond to the antibodies targeting PD-1 or PD-L1, indicating these antibodies may only works in a subset of certain cancers. Thus, understanding the novel function of PD-1 and genetic determinants of response to anti-PD-1 therapy will allow us to develop a more effective and individualized immunotherapeutic strategy for cancer.

Based on the concept that cancer cells may employ several mechanisms to escape immune recognition and elimination of their host, cancer immunotherapy is developed [1]. The aim of cancer immunotherapy is to activate a patient's own immune system to kill the tumor cells [2]. Over the past several decades, a large number of immunotherapeutic approaches to cancer treatment have been established, including cancer vaccines, adoptive transfer of ex vivo activated $\mathrm{T}$ and natural killer cells, anticancer monoclonal antibodies and the checkpoint inhibitors such as anti-PD-1 [3].

PD-1 (also CD279), a coinhibitory receptor expressed on the surface of activated $T$ cells and $B$ cells, has been linked to immune tolerance and therefore provides a possible mechanism of escape immune surveillance when tumor cells become capable of expressing PD-L1 $[4,5]$. PD-1 is mainly activated by interacting with its ligands PD-L1 and PD-L2 [6, 7]. PDL1 is widely distributed on diverse cell types in lymphoid and nonlymphoid tissues, whereas PD-L2 is mainly expressed on dendritic cells (DCs) and some macrophages $[8,9]$. Once activated, PD- 1 exerts a negative effect on immune responses by dephosphorylating key downstream proteins of the antigen receptor $[10,11]$. Thus, the PD-1 pathway may serve as an important regulator for the induction and maintenance of peripheral immune tolerance.

PD-1 expression by tumor-infiltrating lymphocytes 
(TILs) was proved to correlate with impaired immune responses and poor outcome in several tumor types [12, 13]. However, there is a controversial report regarding the prognostic implication of PD-1 positive $(+)$ TILs in cancer patients. Kim and colleagues found that increased numbers of PD-1(+) TILs were significantly associated with prolonged disease-free survival of pulmonary squamous cell carcinoma (SqCC) patients [14]. So the role of PD-1(+) TILs in the prognosis of cancer patients remains unresolved. The expression of PD-L1 has been shown to be correlated with poor prognosis in patients with non-small-cell lung cancer (NSCLC), breast cancer, gastric cancer, soft tissue sarcomas and meningioma [15-19]. Tumor cells may upregulate PD-L1 expression as a way to suppress the host immune response and therefore escape immune destruction. These data provide a clearer understanding of the PD-1/PD-L1 pathway that limits an antitumor immune response and lead to the development of several anticancer drugs by blocking the distinct checkpoints PD-1 or its major ligand PD-L1. As a potential new anticancer strategy, the checkpoint inhibitors anti-PD-1 and anti- PD-L1 have attracted an enormous amount of interest and generated an encouraging clinical outcome in the treatment of patients with solid tumors, particularly in NSCLC, renal cell carcinoma and melanoma [20, 21]. However, not all the cancer patients can gain the benefit from this treatment. For instance, anti-PD-1 antibody produced objective responses only in approximately one in four to one in five patients with NSCLC, melanoma, or renal cell cancer [22], indicating that the genetic background of cancer patients might determine the clinical responses to anti-PD-1 and antiPD-L1 treatments. The answer to this critical issue will provide us increased understanding of response to antiPD-1 therapy and promote the individualized application of these agents in the clinic.

In this review we will summarize the antineoplastic properties of PD-1 pathway as a rheostat of immunological regulation and discuss the genetic determinants of manipulating this strategy for cancer therapy.

\section{THE ROLE OF PD-1/PD-L1 PATHWAY IN CELL IMMUNE RESPONSE}

PD-1, a member of the immunoglobulin (Ig) superfamily, contains an immunoreceptor tyrosine-based inhibitory motif (ITIM) as well as an immunoreceptor tyrosine switch motif (ITSM) in its cytoplasmic tail and delivers inhibitory signals to immune cells upon the binding of its ligand, PD-L1 or PD-L2 [23]. PD-1 is expressed on peripheral $\mathrm{T}$ cells, $\mathrm{B}$ cells, natural killer T (NKT) cells, DCs and some monocytes upon their activation [24]. The immediate outcome of PD-1 engagement via binding with its ligand is inhibition of cell growth and cytokine secretion (Figure 1).



Figure 1: The role of PD-1/PD-L1 pathway in cell immune response. PD-1 functions to inhibit $\mathrm{T}$ cell activation not only by attenuating TCR signaling (SHP-1/2), but also by enhancing the expression of genes that impair T cell function. PI3K-Akt-mTOR, JNK, and Ras-MEK-ERK signals are crucial regulators for PD-1-mediated inhibitory effect on T cell immune. PD-L2 is mainly expressed on B cells. Oct2 can regulate PD-L2 gene expression in B-1 cells and at low antigen concentrations, PD-L2-PD-1interactions suppressed B cell function by inhibiting TCR-B7-CD28 signals. 
PD-1 engagement may directly inhibit T cell antigen receptor (TCR)-mediated effector functions within tissues via recruiting phosphatases such as SHP-1 and SHP-2 [25], which is essential for the maintenance of immune tolerance. PD-1 negatively regulates innate immune cells, the failure of which can cause the activation of autoimmunity [26]. Interactions between PD-1 and PDL1 promoted tolerance by blocking the TCR-induced stop signal in the pancreatic islets, and blockade of PD-1 or PD-L1 suppressed T cell motility and abrogated peripheral tolerance [27]. In vivo, PD-1 deficiency induced autoimmunity in variety of spontaneous autoimmune diseases depending on the genetic background of the mice. The mice genetically lacking PD-1 developed dilated cardiomyopathy through the exhibition of hightiter circulating IgG autoantibodies to troponin I on the BALB/c background [28, 29]. PD-1 deficiency specifically accelerated the onset and frequency of type I diabetes in nonobese diabetic (NOD) mice [30]. Overexpression of PD-1 in DCs inhibited allogeneic lymphocyte activation in BALB/c mice [31]. Those observations suggest that PD-1 may regulate both innate responses and lymphocyte responses to prevent autoimmunity.

PD-1 functions to limit $\mathrm{T}$ cell activation not only by attenuating TCR signaling, but also by enhancing the expression of genes that impair $\mathrm{T}$ cell function. PD-1 coordinately upregulated the expression of transcription factor ATF-like (BATF) which was sufficient to impair T cell proliferation and cytokine secretion [32]. Silencing BATF in T cells reduced PD-1 inhibition and rescued HIV-specific T cell function. PD-1 altered T-cell metabolic reprogramming by inhibiting glycolysis and promoting lipolysis and fatty acid oxidation, which reveal a metabolic mechanism responsible for PD-1-mediated blockade of T-cell effector function [33]. Triggering of PD-1 inhibited $\mathrm{T}$ cell expansion and function by upregulating IL-10 production [34]. Blockade of PD-1 increased the activation of phosphatidylinositol-3-kinase (PI3K) and its downstream targets AKT and mammalian target of rapamycin (mTOR), which are impaired in antiviral cytotoxic T lymphocytes (CTLs). In the further study, the transcription factor FoxO1 was demonstrated to be responsible for sustaining the expression and function of PD-1 in exhausted CTLs [35]. Some other transcription factors are also involved in regulation of PD-1 expression. Mutation of Nuclear factor of activated $\mathrm{T}$ cells $\mathrm{c} 1$ (NFATc1) resulted in a complete loss of PD-1 expression in $T$ cells [36]. The interferon (IFN)-sensitive responsive element (ISRE) was shown to be essential for IFN-alphainduced upregulation of PD-1 in macrophages [37]. NF$\kappa \mathrm{B}$ regulated PD-1 expression in macrophages through binding the site located upstream of the gene in conserved region $\mathrm{C}$ [38]. In addition, PD-1 can be selectively triggered by ligation of Toll-like receptor 9, which contributes to peripheral tolerance and autoimmunity [39]. PD-1 also affected cell cycle progression and proliferation of T lymphocytes by suppressing the ubiquitin ligase SCF (Skp2) through inhibiting PI3K-Akt and Ras-mitogenactivated and extracellular signal-regulated kinase kinase (MEK)-extracellular signal-regulated kinase (ERK) signaling pathways [40].

PD-L1 is induced on various cell types in response to certain inflammatory cytokines (primarily IFN- $\gamma$ ), which are produced during the immune responses of $\mathrm{T}$ and natural killer (NK) cells [41]. IFN- $\gamma$-stimulated neutrophils suppressed lymphocyte proliferation through expression of PD-L1 [42]. The common gamma-chain cytokines IL2, IL-7, IL-15, and IL-21 induced the expression of PDL1, resulting in suppressing certain effector functions of cytokine-stimulated cells upon TCR engagement [43]. The inflammatory cytokines (such as IL-17 and IFN- $\gamma$ )triggered up-regulation of PD-L1 on RPE played a critical factor for inducing infiltrated uveitogenic $\mathrm{T}$ cells with regulatory activities [44]. Recent studies indicate that the Janus kinase (JAK)/STAT and mitogen-activated protein kinase (MAPK) signaling pathways were involved in IFNinduced PD-L1 expression [45, 46]. Signal transducer and activator of transcription 3 (STAT3) with binding to the CD274 gene promoter was also required for PD-L1 gene expression [47], moreover, STAT3-dependent upregulation of PD-L1 mediated immune regulatory functions of liver plasmacytoid DCs [48].

PD-L2, a second ligand for PD-1, is mainly expressed on B cells, DCs, macrophages, and cultured bone marrow (BM)-derived mast cells. Engagement of PD-1 by PD-L2 may dramatically suppress TCR-mediated proliferation and cytokine production by CD4+ T cells. The expression of PD-L2 also varies depending on the antigen concentrations [7]. At low antigen concentrations, PD-L2-PD-1interactions suppressed TCR-B7-CD28 signals. In contrast, at high antigen concentrations, PD-L2PD-1 interactions attenuated cytokine production but did not inhibit $\mathrm{T}$ cell proliferation. There are few reports about transcriptional regulation of PD-L2. Octamer binding protein 2 (Oct2) was demonstrated to regulate PD-L2 gene expression in B-1 cells through lineage-specific activity of a unique, intronic promoter [49]. Subsequently, PD-L2 cross-linking induced $\mathrm{NF}-\kappa \mathrm{B}$-dependent protection of dendritic cells from cell death [50].

\section{THE ROLE OF PD-1/PD-L1 PATHWAY IN CANCER}

The PD-1/PD-L1 pathway has a crucial role in regulating immunosurveillance for tumors. PD-1 can interfere with TCR/CD28 signals to suppress the immune responses of T-cell help (Tc1/Th1 skewing) in the tumor microenvironment through the PD-1/SHP-2/p-STAT1/Tbet axis [51]. Tumor cells expressing PD-1 can limit the activity of tumor antigens (TA)-specific $\mathrm{CD} 8^{+} \mathrm{T}$ cells, which reinforces their growth and invasiveness [52]. PD-1 is upregulated by dysfunctional TA-specific $\mathrm{CD} 8^{+} \mathrm{T}$ cells 
both in vitro and in vivo [53], and PD-1 blockade enhances TA-specific $\mathrm{T}$ cell responses and inhibits tumor growth or partial tumor regression [54]. PD-1 blockade also increases T-cell migration to tumors by elevating IFN- $\gamma$ inducible chemokines, which augments T-cell-mediated antitumor responses [55]. In addition, the majority of TILs predominantly express high levels of PD-1 and are thought to be correlated with an "exhausted" phenotype and impaired antitumor immune responses [56]. This "exhausted" phenotype is marked by decreased T cell proliferation, poor cytolytic activity, and low production of type I cytokines.

PD-L1 and PD-L2 expression are up-regulated in a variety of human cancer types. PD-L1 is frequently expressed in several types of solid tumor cells, whereas PD-L2 is highly expressed in certain subsets of B cell lymphomas [57-59]. Expression of PD-L1 protein significantly correlates with the levels of elevated TILs, which is associated with cancer metastasis [60]. Transgenic expression of PD-L1 in immunogenic tumor cells confers them a potent escaping from host $\mathrm{T}$ cell immunity and markedly enhances their invasiveness in vivo [61]. PD-L1 is also upregulated in tumors by activation of key signaling pathways including PI3K, STAT3, IFN- $\gamma$ and so on. Latent membrane protein 1 (LMP1) and IFN- $\gamma$ upregulate PD-L1 through STAT3, AP-1, and NF- $\kappa \mathrm{B}$ pathways, which promotes progression of nasopharyngeal carcinoma (NPC) and ovarian cancer $[41,62]$. The activation of MAPK promotes PD-L1 expression that is transcriptionally modulated by c-Jun and augmented by STAT3 [63]. Similarly, PD-L2 expression is observed in a subset of tumor types but its role in cancer is far less prevalent than PD-L1. PD-L2 expression in pulmonary squamous cell carcinoma is associated with an increased number of $\mathrm{CD}^{+} \mathrm{TILs}$ and proto-oncogene MET protein overexpression [14].

\section{PD-1/PD-L1 BLOCKADE AND ITS CLINICAL APPLICATION}

Based on the concept that the blockade of PD-1 or its ligands has immune-potentiating effects on cancer cells, many monoclonal antibodies targeting PD-1/PD-L1 pathway have been developed for the treatment of various cancer types (Table 1). Among these anti-PD-1 antibodies, nivolumab and pembrolizumab, have been approved by the US Food and Drug Administration (FDA) for the treatment of patients with metastatic melanoma.

\section{Nivolumab}

Nivolumab (also known as ONO-4538, BMS936558 or MDX-1106) is a genetically engineered, fully human immunoglobulin $(\mathrm{Ig}) \mathrm{G}_{4}$ immune checkpoint inhibitor specifically targeting for human PD-1. The antibody binds to PD-1 with high affinity, thereby attenuating inhibitory signals and enhancing the host antitumor immune responses. Nivolumab has anticancer potential in a variety of tumor types, including melanoma, NSCLC, prostate cancer, renal cell carcinoma (RCC), Hodgkin's lymphoma and colorectal cancer (CRC). The first report of the safety and antitumor activity of nivolumab was a phase I dose escalation trial [64]. In this study, nivolumab was showed to have significant antitumor activity but a maximum tolerated dose was not confirmed. Since then, a large amount of clinic trials investigate the association between nivolumab exposure and various cancer types. Recently, Nivolumab was approved by the US FDA in December 2014 for the treatment of patients with unresectable or metastatic melanoma. Nivolumab was also approved by the US FDA for the treatment of patients with metastatic squamous NSCLC that returns during or after treatment with platinum-based chemotherapy in March 2015.

Melanoma is considered an "immunogenic" tumor and high levels of PD-L1 are frequently expressed in melanomas, leading to activation of PD-1 and downregulation of anticancer immunity [65]. Thus, immune checkpoint antibodies may have antitumor potential for patients with melanoma (Table 2). A randomized phase I clinical trial showed that nivolumab treatment could significantly improve the median progression-free survival (PFS), overall survival (OS) and objective response rate (ORR) [66]. Importantly, the responses were durable and long-term safety was acceptable. To date, no authoritative phase II clinical trials had been reported. A phase III study evaluated nivolumab versus dacarbazine in previously untreated melanoma without BRAF mutation [67]. This study suggested nivolumab significantly improved the OS and PFS in previously untreated patients who had metastatic melanoma without a BRAF mutation. Another randomised, controlled, open-label, phase III trial assessed the efficacy and safety of nivolumab versus investigator's choice of chemotherapy (ICC) as a second-line or laterline treatment in patients with advanced melanoma [68]. As a result, ORR in nivolumab patients was reported to be higher than that in ICC patients. Moreover, BRAF wildtype patients treated with nivolumab showed a better ORR than that in $\mathrm{BRAF}^{\mathrm{V} 600}$ mutation-positive patients. This clinical trial indicated that nivolumab represented a new treatment option for the patients with advanced melanoma that has progressed after ipilimumab or ipilimumab and a BRAF inhibitor.

Similar to melanoma, NSCLC displays high expression of PD-1 or PD-L1 [69] and blocking PD-1/ PD-L1 pathway as a therapeutical strategy was recently evaluated in the patients with NSCLC (Table 2). The phase I dose-escalation cohort expansion trial showed nivolumab is effective and safe for the patients with previously treated advanced NSCLC [70]. A phase II, single-arm trial 
Table 1: Currently used anti-PD-1 and anti-PD-L1 antibodies

\begin{tabular}{|c|c|c|c|c|}
\hline Target & Name & Molecule & Manufacturer & Phase \\
\hline \multirow{3}{*}{ anti-PD-1 } & Nivolumab & Fully human IgG4 & Bristol-Myers Squibb & I-III \\
\cline { 2 - 5 } & Pembrolizumab & Humanized IgG4 & Merck\& Dohme & I-III \\
\cline { 2 - 5 } & Pidilizumab & Humanized IgG1 & CureTech & I-II \\
\hline anti-PD-L1 & MPDL3280A & Engineered human IgG1 & Roche/Genentech & I-III \\
\hline & BMS-936559 & Humanized IgG4 & Bristol-Myers Squibb & I \\
\hline & MEDI4736 & Engineered human IgG1 & MedImmune & I-III \\
\hline & MSB0010718C & Fully human IgG1 & EMD Serono & I-II \\
\hline
\end{tabular}

indicated a positive activity of nivolumab for the patients with advanced, refractory, squamous NSCLC [71]. These data support that nivolumab has antitumor activity and a manageable safety profile in previously treated patients with advanced, refractory, squamous NSCLC. On the basis of these encouraging results, phase III clinical trials are further evaluating the activity of nivolumab in patients with NSCLC.

$\mathrm{RCC}$ is considered as an immunogenic tumor with dysfunctional immune cell infiltrate and PD-L1 expression correlates with increased risk of disease progression and cancer-specific death of the patients with this cancer type [72]. Thus, PD-1 can function as an emerging therapeutic target in RCC (Table 2). A phase I study with expansion cohorts evaluated clinical activity, survival, and longterm safety in patients with advanced RCC treated with nivolumab [73]. As a result, median OS (22.4 months) is encouraging, and toxicities were generally manageable. The randomized phase II trial assessed the antitumor activity, dose-response relationship, and safety of nivolumab in patients with metastatic RCC [74]. This report demonstrated nivolumab had antitumor activity with a manageable safety profile across the three doses studied in metastatic RCC. A number of ongoing phase III studies that will further elucidate this evidence.

In addition, nivolumab emerges antitumor potential in Hodgkin's lymphoma (Table 2). To determine whether nivolumab could inhibit tumor immune evasion in patients with Hodgkin's lymphoma, 23 patients with relapsed or refractory Hodgkin's lymphoma received the treatment with nivolumab. As a result, nivolumab had substantial therapeutic activity and an acceptable safety profile in patients with previously heavily treated relapsed or refractory Hodgkin's lymphoma [58]. Several results from phase II and III clinical trials are awaited yet.

\section{Pembrolizumab}

Pembrolizumab (MK-3475), a humanized $\mathrm{IgG}_{4}$ monoclonal antibody blocking the interaction of PD-1 on $\mathrm{T}$ cells with its ligands, is believed to reactivate antitumor immunity (Table 2). A phase I trial assessed the efficacy and safety of pembrolizumab in patients with ipilimumabrefractory advanced melanoma [75]. This study suggested that pembrolizumab could be an effective treatment option for patients with ipilimumab-refractory advanced melanoma. The randomized, controlled, phase III trial compared pembrolizumab with ipilimumab in 834 patients with advanced melanoma [76]. The results showed that pembrolizumab could prolong PFS and OS and had less high-grade toxicity than did ipilimumab in patients with advanced melanoma.

In NSCLC, the efficacy and safety of pembrolizumab is currently being investigated in a phase I trial [77]. It was indicated that pembrolizumab had antitumor activity in patients with advanced NSCLC, moreover, PD-L1 expression in at least $50 \%$ of tumor cells was shown to be correlated with improved efficacy of pembrolizumab. In addition, pembrolizumab is currently being investigated in a phase I/II trial in the patients with some other cancer types, including breast cancer, bladder cancer, and haematologic malignancies.

\section{Pidilizumab}

Pidilizumab (CT-011) is a humanized $\mathrm{IgG}_{1}$ kappa recombinant monoclonal antibody against $\mathrm{PD}-1$. In preclinical studies, pidilizumab was demonstrated to inhibit cancer cells survival (Table 2) [78]. In a phase I clinical trial, pidilizumab was shown to be safe and well tolerated in patients with advanced hematological malignancies, and no single maximum tolerated dose was defined in this study [79]. Two phase II trials assessed the safety and activity. One evaluated the antitumor activity of pidilizumab in diffuse large B-cell lymphoma (DLBCL) [80]. The other trial enrolled 32 patients with relapsed follicular lymphoma and these patients were received the treatment with the combination of pidilizumab and rituximab [81]. These two trials suggested pidilizumab was worthy of further study in follicular lymphoma. Currently, the efficacy and safety of pidilizumab is underway in other tumor types.

\section{Other anti-PD-L1 antibodies}

MPDL3280A, an engineered human anti-PD-L1 monoclonal $\mathrm{IgG}_{1}$ antibody, has noteworthy antitumor activity in metastatic urothelial bladder cancer (UBC) [82]. MPDL3280A is currently being investigated in 
Table 2: Efficacy data of anti-PD-1 and anti-PD-L1 antibodies

\begin{tabular}{|c|c|c|c|c|c|c|c|c|}
\hline Antibody & Phase & $\begin{array}{l}\text { Patients } \\
\text { (Number) }\end{array}$ & Dose & Tumor & ORR\% & $\begin{array}{l}\text { Median } \\
\text { OS, months } \\
(95 \% \text { CI })\end{array}$ & $\begin{array}{c}\text { PFS months } \\
(95 \% \mathrm{CI})\end{array}$ & Reference \\
\hline \multirow[t]{8}{*}{ Nivolumab } & I & 107 & $\begin{array}{c}0.1-10 \mathrm{mg} / \\
\mathrm{kg}\end{array}$ & Advanced melanoma & 31 & $\begin{array}{c}16.8 \\
(12.5-31.6)\end{array}$ & $\begin{array}{c}3.7 \\
(1.9-9.1)\end{array}$ & 66 \\
\hline & III & 418 & $3 \mathrm{mg} / \mathrm{kg}$ & Advanced melanoma & 40 & Unknown & $\begin{array}{c}5.1 \\
(0.34-0.56) \\
\end{array}$ & 67 \\
\hline & III & 631 & $3 \mathrm{mg} / \mathrm{kg}$ & Advanced melanoma & 31.7 & Unknown & $\begin{array}{c}4.7 \\
(2.3-6.5) \\
\end{array}$ & 68 \\
\hline & I & 129 & $\begin{array}{l}1,3,10 \\
\mathrm{mg} / \mathrm{kg}\end{array}$ & Advanced NSCLC & 17 & $\begin{array}{c}9.9 \\
(7.8-12.4) \\
\end{array}$ & $\begin{array}{c}2.3 \\
(1.8-3.7) \\
\end{array}$ & 70 \\
\hline & II & 117 & $3 \mathrm{mg} / \mathrm{kg}$ & Squamous NSCLC & 14.5 & $\begin{array}{c}8.2 \\
(6.1-10.9) \\
\end{array}$ & $\begin{array}{c}1.9 \\
(1.8-3.2) \\
\end{array}$ & 71 \\
\hline & I & 34 & $\begin{array}{l}1 \text { or } 10 \\
\mathrm{mg} / \mathrm{kg}\end{array}$ & Advanced RCC & 29 & $\begin{array}{c}22.4 \\
(12.5-\mathrm{NE}) \\
\end{array}$ & $\begin{array}{c}7.3 \\
(3.6-10.9) \\
\end{array}$ & 73 \\
\hline & II & 168 & $\begin{array}{l}0.3,2,10 \\
\mathrm{mg} / \mathrm{kg}\end{array}$ & Advanced RCC & $\begin{array}{c}20 \text { for } 0.3 \\
22 \text { for } 2 \\
20 \text { for } 10\end{array}$ & $\begin{array}{c}20 \text { for } 0.3 \\
22 \text { for } 2 \\
20 \text { for } 10\end{array}$ & $\begin{array}{c}18.2 \text { for } 0.3 \\
25.5 \text { for } 2 \\
24.7 \text { for } 10\end{array}$ & 74 \\
\hline & I & 23 & $3 \mathrm{mg} / \mathrm{kg}$ & $\begin{array}{l}\text { Hodgkin's } \\
\text { lymphoma }\end{array}$ & 87 & Unknown & Unknown & 58 \\
\hline \multirow[t]{3}{*}{ Pembrolizumab } & I & 173 & $\begin{array}{l}2 \text { or } 10 \\
\mathrm{mg} / \mathrm{kg}\end{array}$ & Advanced melanoma & 26 & Unknown & $\begin{array}{c}5.5 \text { for } 2 \\
3.5 \text { for } 10 \\
\end{array}$ & 75 \\
\hline & III & 834 & $\begin{array}{c}10 \\
\mathrm{mg} / \mathrm{kg}\end{array}$ & Advanced melanoma & $\begin{array}{l}33.7 \text { for } \\
\text { every } 2 \\
\text { weeks } \\
32.9 \text { every } \\
3 \text { weeks } \\
\end{array}$ & Unknown & Unknown & 76 \\
\hline & I & 495 & $\begin{array}{l}2 \text { or } 10 \\
\mathrm{mg} / \mathrm{kg}\end{array}$ & Advanced NSCLC & 19.4 & 12 & 3.7 & 77 \\
\hline \multirow[t]{3}{*}{ Pidilizumab } & I & 17 & $\begin{array}{c}0.2 \text { to } 6.0 \\
\mathrm{mg} / \mathrm{kg}\end{array}$ & $\begin{array}{c}\text { Hematolog-ical } \\
\text { malignancies }\end{array}$ & Unknown & Unknown & Unknown & 79 \\
\hline & II & 66 & $1.5 \mathrm{mg} / \mathrm{kg}$ & DLBCL & 51 & Unknown & Unknown & 80 \\
\hline & II & 32 & $3 \mathrm{mg} / \mathrm{kg}$ & Lymphoma & 66 & Unknown & Unknown & 81 \\
\hline
\end{tabular}

combination with dabrafenib, vemurafenib or trametinib in advanced melanoma with or without BRAF mutation. The phase II/III trials of MPDL3280A in advanced NSCLC, metastatic RCC, and breast cancer are also ongoing.

MEDI4736, an engineered fully-human anti-PD-L1 antibody, has been reported to have an ORR in 13\% across all the patients with lung cancer, but up to $39 \%$ in PD$\mathrm{Ll}^{+}$patients and $5 \%$ in PD-L1 negative patients [83]. Based on these outcomes in lung cancer, several clinical trials for MEDI4736, both as monotherapy as well as in combination with other agents, is underway across a range of tumor types.

\section{THE GENETICDETERMINANTS OFANTI- PD-1/ PD-L1 ANTIBODIES RESPONSE}

Although a number of studies have reported that anti-PD-1/ PD-L1 antibodies exhibit antitumor immune responses in variety of cancer types, significant interindividual variability in response attenuates its optimal use. This may attribute to the various genetic backgrounds of the different tumor types. Thus, it will be important to understand why some cancer patients are sensitive to these antibodies, what are the genetic determinants of response to this therapy.

Although early studies indicated that PD-L1 expression may be a predictable biomarker for therapeutic response to anti-PD-1 antibodies, only a subset of patients with NSCLC responded to PD-1 blockade, indicating the genetic background of the cancer patients may be a key determinant of response to this therapy. PD-L1 expression in at least $50 \%$ of NSCLC cells correlated with improved efficacy of pembrolizumab [77]. Recently, it was shown that high PD-L1 expression was associated with the presence of epidermal growth factor receptor (EGFR) mutation in advanced lung adenocarcinoma and PDL1 overexpression was considered as a poor prognostic indicator in EGFR wild-type patients but not in EGFR mutant patients [84]. Another study demonstrated that EGFR mutant tumors display elevated PD-L1 levels and the EGFR mutant mouse showed significant response to the treatment with anti-PD-1 antibody, indicating EGFR mutation may be a promising biomarker of response to this treatment [85]. In addition, higher nonsynonymous mutation burden, the molecular smoking signature, higher 
neoantigen burden, and DNA repair pathway mutations were also showed to determine sensitivity to PD-1 blockade in NSCLC [86]. Moreover, long-term clinical benefit from anti-PD-L1 therapy in lung cancer was also discovered to be associated with JAK3 activation [87].

PD-L1 expression in advanced melanoma was thought to be correlated with response to monoclonal antibodies targeting PD-1/PD-L1 pathway, moreover, the sensitivity to PD-1/PD-L1 blocking antibodies seemed to be more robust in patients whose tumors express PDL1 [88, 89]. However, the potential relationship between the BRAF mutation and PD-L1 expression has not been determined. Several recent reports demonstrated that PDL1 expression did not correlate with BRAF mutational status in melanoma and lung adenocarcinomas [90, 91]. Thus, the BRAF mutational status does not play a major role in directly determining the efficiency of PD-1 pathway blockade in melanoma cells. Recently, NRAS mutations in advanced melanoma were correlated with increased benefit from anti-PD-1/PD-L1 therapy compared with other genetic subtypes [92].

PD-L1 mRNA expression was identified to be associated with increased tumor-infiltrating immune cells and better outcome in breast carcinomas [93]. In patients with $\mathrm{RCC}$, the presence of $\mathrm{PD}-1(+)$ tumorinfiltrating immune cells was associated with more aggressive tumors and shortened survival [12]. The responses of MPDL3280A were observed in patients with high expression of PD-L1, especially when PD-L1 was expressed by tumor-infiltrating immune cells. In addition, T-helper type $1\left(\mathrm{~T}_{\mathrm{H}} 1\right)$ gene expression, CTLA4 expression and the absence of fractalkine (CX3CL1) in baseline tumor specimens were also related with the response to the anti-PD-L1 antibody MPDL3280A in cancer patients [94]. The pre-existing CD8+ T cells were shown to be associated with expression of the PD-1/PD-L1 immune inhibitory axis and may predict response to PD-1 blockade [95]. The mismatch repair deficiency is also considered as a genomic marker to predict response to PD-1 blockade with pembrolizumab in colorectal and other cancers [96].

Taken together, these molecular targets are important for design of future clinical trials assessing the antitumor potential of anti-PD-1/ PD-L1 antibodies.

\section{CONCLUSION AND THERAPEUTIC PERSPECTIVES}

Immune checkpoint modulation as a therapeutic strategy is attracting more and more attention in cancer therapy. Increasing data from pre-clinical studies and clinical trials have confirmed that anti-PD-1/PD-L1 antibodies have antitumor potential and improve cancer patients' survival. Currently, anti-PD-1 or anti-PD-L1 therapy is under individual study and in combination with other therapies such as cytotoxic chemotherapy, antiangiogenic agents and small-molecule tyrosine kinase inhibitors.

Nevertheless, this treatment raises many issues. First, it is not exactly clear how PD-1 mediates their effects since the possible molecular mechanisms by which anti-PD-1/PD-L1 antibodies enhance the host antitumor immune responses remain elusive. Secondly, to maximize the potential to be applied for more stringent clinical study, the efficacy and safety of PD-1/PD-L1 targeting antibodies should be further investigated. Thirdly, the determinants of the immune responses of these agents are still unknown. Thus, it is urgent to discern more sensitive and specific predictors of clinical outcomes in order to identify patients who will benefit the most from the clinical treatment. However, our increased understanding of PD-1 mediated signal pathways will hopefully broaden the number of therapeutic targets and perhaps provide a prospective strategy for cancer by modulating the immune checkpoints.

\section{ACKNOWLEDGMENTS}

This study is supported by grants from National Natural Science Foundation of China (grant No. 81301891), Zhejiang Provincial Natural Science Foundation of China (grant No. LQ13H160008), Zhejiang province science and technology project of TCM (grant No. 2015ZB033) and Zhengshu Medical Elite Scholarship Fund.

\section{CONFLICTS OF INTEREST}

The authors declare no conflict of interest.

None of the contents of this manuscript has been previously published or is under consideration elsewhere. All the authors read and approved the final version of the manuscript prior to submission.

\section{REFERENCES}

1. Mueller KL. Cancer immunology and immunotherapy. Realizing the promise. Introduction. Science. 2015; 348:5455.

2. McNutt M. Cancer immunotherapy. Science. 2013; 342:1417.

3. Topalian SL, Weiner GJ and Pardoll DM. Cancer immunotherapy comes of age. Journal of clinical oncology : official journal of the American Society of Clinical Oncology. 2011; 29:4828-4836.

4. Nishimura $\mathrm{H}$, Minato $\mathrm{N}$, Nakano $\mathrm{T}$ and Honjo $\mathrm{T}$. Immunological studies on PD-1 deficient mice: implication of PD-1 as a negative regulator for $\mathrm{B}$ cell responses. International immunology. 1998; 10:1563-1572.

5. Ferris R. PD-1 targeting in cancer immunotherapy. Cancer. 2013; 119:E1-3.

6. Freeman GJ, Long AJ, Iwai Y, Bourque K, Chernova 
T, Nishimura H, Fitz LJ, Malenkovich N, Okazaki T, Byrne MC, Horton HF, Fouser L, Carter L, Ling V, Bowman MR, Carreno BM, et al. Engagement of the PD-1 immunoinhibitory receptor by a novel B7 family member leads to negative regulation of lymphocyte activation. The Journal of experimental medicine. 2000; 192:1027-1034.

7. Latchman Y, Wood CR, Chernova T, Chaudhary D, Borde M, Chernova I, Iwai Y, Long AJ, Brown JA, Nunes R, Greenfield EA, Bourque K, Boussiotis VA, Carter LL, Carreno BM, Malenkovich N, et al. PD-L2 is a second ligand for PD-1 and inhibits $\mathrm{T}$ cell activation. Nature immunology. 2001; 2:261-268.

8. Yamazaki T, Akiba H, Iwai H, Matsuda H, Aoki M, Tanno Y, Shin T, Tsuchiya H, Pardoll DM, Okumura K, Azuma $\mathrm{M}$ and Yagita H. Expression of programmed death 1 ligands by murine T cells and APC. Journal of immunology. 2002; 169:5538-5545.

9. Ishida M, Iwai Y, Tanaka Y, Okazaki T, Freeman GJ, Minato $\mathrm{N}$ and Honjo T. Differential expression of PD-L1 and PD-L2, ligands for an inhibitory receptor PD-1, in the cells of lymphohematopoietic tissues. Immunology letters. 2002; 84:57-62.

10. Okazaki T, Maeda A, Nishimura H, Kurosaki T and Honjo T. PD-1 immunoreceptor inhibits B cell receptor-mediated signaling by recruiting src homology 2-domain-containing tyrosine phosphatase 2 to phosphotyrosine. Proceedings of the National Academy of Sciences of the United States of America. 2001; 98:13866-13871.

11. Sheppard KA, Fitz LJ, Lee JM, Benander C, George JA, Wooters J, Qiu Y, Jussif JM, Carter LL, Wood CR and Chaudhary D. PD-1 inhibits T-cell receptor induced phosphorylation of the ZAP70/CD3zeta signalosome and downstream signaling to PKCtheta. FEBS letters. 2004; 574:37-41.

12. Thompson RH, Dong H, Lohse CM, Leibovich BC, Blute ML, Cheville JC and Kwon ED. PD-1 is expressed by tumor-infiltrating immune cells and is associated with poor outcome for patients with renal cell carcinoma. Clinical cancer research : an official journal of the American Association for Cancer Research. 2007; 13:1757-1761.

13. Zhang Y, Huang S, Gong D, Qin Y and Shen Q. Programmed death-1 upregulation is correlated with dysfunction of tumor-infiltrating CD8+ T lymphocytes in human non-small cell lung cancer. Cellular \& molecular immunology. 2010; 7:389-395.

14. Kim MY, Koh J, Kim S, Go H, Jeon YK and Chung DH. Clinicopathological analysis of PD-L1 and PDL2 expression in pulmonary squamous cell carcinoma: Comparison with tumor-infiltrating $\mathrm{T}$ cells and the status of oncogenic drivers. Lung cancer. 2015; 88:24-33.

15. Anagnostou VK and Brahmer JR. Cancer immunotherapy: a future paradigm shift in the treatment of non-small cell lung cancer. Clinical cancer research : an official journal of the American Association for Cancer Research. 2015; 21:976984.
16. Muenst S, Schaerli AR, Gao F, Daster S, Trella E, Droeser RA, Muraro MG, Zajac P, Zanetti R, Gillanders WE, Weber WP and Soysal SD. Expression of programmed death ligand 1 (PD-L1) is associated with poor prognosis in human breast cancer. Breast cancer research and treatment. 2014; 146:15-24.

17. Qing Y, Li Q, Ren T, Xia W, Peng Y, Liu GL, Luo H, Yang YX, Dai XY, Zhou SF and Wang D. Upregulation of PD-L1 and APE1 is associated with tumorigenesis and poor prognosis of gastric cancer. Drug design, development and therapy. 2015; 9:901-909.

18. Kim JR, Moon YJ, Kwon KS, Bae JS, Wagle S, Kim KM, Park HS, Lee H, Moon WS, Chung MJ, Kang MJ and Jang KY. Tumor infiltrating PD1-positive lymphocytes and the expression of PD-L1 predict poor prognosis of soft tissue sarcomas. PloS one. 2013; 8:e82870.

19. Du Z, Abedalthagafi M, Aizer AA, McHenry AR, Sun HH, Bray MA, Viramontes O, Machaidze R, Brastianos PK, Reardon DA, Dunn IF, Freeman GJ, Ligon KL, Carpenter AE, Alexander BM, Agar NY, et al. Increased expression of the immune modulatory molecule PD-L1 (CD274) in anaplastic meningioma. Oncotarget. 2015; 6:4704-4716.

20. Sunshine J and Taube JM. PD-1/PD-L1 inhibitors. Current opinion in pharmacology. 2015; 23:32-38.

21. Luke JJ and Ott PA. PD-1 pathway inhibitors: the next generation of immunotherapy for advanced melanoma. Oncotarget. 2015; 6:3479-3492.

22. Topalian SL, Hodi FS, Brahmer JR, Gettinger SN, Smith DC, McDermott DF, Powderly JD, Carvajal RD, Sosman JA, Atkins MB, Leming PD, Spigel DR, Antonia SJ, Horn L, Drake CG, Pardoll DM, et al. Safety, activity, and immune correlates of anti-PD-1 antibody in cancer. The New England journal of medicine. 2012; 366:2443-2454.

23. Okazaki T and Honjo T. PD-1 and PD-1 ligands: from discovery to clinical application. International immunology. 2007; 19:813-824.

24. Keir ME, Butte MJ, Freeman GJ and Sharpe AH. PD-1 and its ligands in tolerance and immunity. Annual review of immunology. 2008; 26:677-704.

25. Parry RV, Chemnitz JM, Frauwirth KA, Lanfranco AR, Braunstein I, Kobayashi SV, Linsley PS, Thompson CB and Riley JL. CTLA-4 and PD-1 receptors inhibit T-cell activation by distinct mechanisms. Molecular and cellular biology. 2005; 25:9543-9553.

26. Rui Y, Honjo T and Chikuma S. Programmed cell death 1 inhibits inflammatory helper T-cell development through controlling the innate immune response. Proceedings of the National Academy of Sciences of the United States of America. 2013; 110:16073-16078.

27. Fife BT, Pauken KE, Eagar TN, Obu T, Wu J, Tang Q, Azuma M, Krummel MF and Bluestone JA. Interactions between PD-1 and PD-L1 promote tolerance by blocking the TCR-induced stop signal. Nature immunology. 2009; 10:1185-1192. 
28. Nishimura H, Okazaki T, Tanaka Y, Nakatani K, Hara M, Matsumori A, Sasayama S, Mizoguchi A, Hiai H, Minato N and Honjo T. Autoimmune dilated cardiomyopathy in PD-1 receptor-deficient mice. Science. 2001; 291:319-322.

29. Okazaki T, Tanaka Y, Nishio R, Mitsuiye T, Mizoguchi A, Wang J, Ishida M, Hiai H, Matsumori A, Minato $\mathrm{N}$ and Honjo T. Autoantibodies against cardiac troponin I are responsible for dilated cardiomyopathy in PD-1-deficient mice. Nature medicine. 2003; 9:1477-1483.

30. Wang J, Yoshida T, Nakaki F, Hiai H, Okazaki T and Honjo T. Establishment of NOD-Pdcd1-/- mice as an efficient animal model of type I diabetes. Proceedings of the National Academy of Sciences of the United States of America. 2005; 102:11823-11828.

31. Li W, Wang X, Chen R, Zhu H, Chen G and Sun X. Overexpression of programmed death ligand 1 in dendritic cells inhibits allogeneic lymphocyte activation in mice. The Journal of surgical research. 2012; 176:e79-87.

32. Quigley M, Pereyra F, Nilsson B, Porichis F, Fonseca C, Eichbaum Q, Julg B, Jesneck JL, Brosnahan K, Imam S, Russell K, Toth I, Piechocka-Trocha A, Dolfi D, Angelosanto J, Crawford A, et al. Transcriptional analysis of HIV-specific CD8+ T cells shows that PD-1 inhibits $\mathrm{T}$ cell function by upregulating BATF. Nature medicine. 2010; 16:1147-1151.

33. Patsoukis N, Bardhan K, Chatterjee P, Sari D, Liu B, Bell LN, Karoly ED, Freeman GJ, Petkova V, Seth P, Li L and Boussiotis VA. PD-1 alters T-cell metabolic reprogramming by inhibiting glycolysis and promoting lipolysis and fatty acid oxidation. Nature communications. 2015; 6:6692.

34. Said EA, Dupuy FP, Trautmann L, Zhang Y, Shi Y, El-Far M, Hill BJ, Noto A, Ancuta P, Peretz Y, Fonseca SG, Van Grevenynghe J, Boulassel MR, Bruneau J, Shoukry NH, Routy JP, et al. Programmed death-1-induced interleukin-10 production by monocytes impairs CD4 $+\mathrm{T}$ cell activation during HIV infection. Nature medicine. 2010; 16:452-459.

35. Staron MM, Gray SM, Marshall HD, Parish IA, Chen JH, Perry CJ, Cui G, Li MO and Kaech SM. The transcription factor FoxO1 sustains expression of the inhibitory receptor PD-1 and survival of antiviral CD8(+) T cells during chronic infection. Immunity. 2014; 41:802-814.

36. Oestreich KJ, Yoon H, Ahmed R and Boss JM. NFATc1 regulates PD-1 expression upon $\mathrm{T}$ cell activation. Journal of immunology. 2008; 181:4832-4839.

37. Cho HY, Lee SW, Seo SK, Choi IW, Choi I and Lee $\mathrm{SW}$. Interferon-sensitive response element (ISRE) is mainly responsible for IFN-alpha-induced upregulation of programmed death-1 (PD-1) in macrophages. Biochimica et biophysica acta. 2008; 1779:811-819.

38. Bally AP, Lu P, Tang Y, Austin JW, Scharer CD, Ahmed $\mathrm{R}$ and Boss JM. NF-kappaB Regulates PD-1 Expression in Macrophages. Journal of immunology. 2015; 194:45454554.

39. Wong RM, Smith KA, Tam VL, Pagarigan RR, Meisenburg
BL, Quach AM, Carrillo MA, Qiu Z and Bot AI. TLR-9 signaling and TCR stimulation co-regulate CD8(+) T cellassociated PD-1 expression. Immunology letters. 2009; 127:60-67.

40. Patsoukis N, Brown J, Petkova V, Liu F, Li L and Boussiotis VA. Selective effects of PD-1 on Akt and Ras pathways regulate molecular components of the cell cycle and inhibit T cell proliferation. Science signaling. 2012; 5:ra46.

41. Fang W, Zhang J, Hong S, Zhan J, Chen N, Qin T, Tang Y, Zhang Y, Kang S, Zhou T, Wu X, Liang W, Hu Z, Ma Y, Zhao Y, Tian Y, et al. EBV-driven LMP1 and IFNgamma up-regulate PD-L1 in nasopharyngeal carcinoma: Implications for oncotargeted therapy. Oncotarget. 2014; 5:12189-12202.

42. de Kleijn S, Langereis JD, Leentjens J, Kox M, Netea MG, Koenderman L, Ferwerda G, Pickkers P and Hermans PW. IFN-gamma-stimulated neutrophils suppress lymphocyte proliferation through expression of PD-L1. PloS one. 2013; 8:e72249.

43. Kinter AL, Godbout EJ, McNally JP, Sereti I, Roby GA, O'Shea MA and Fauci AS. The common gammachain cytokines IL-2, IL-7, IL-15, and IL-21 induce the expression of programmed death-1 and its ligands. Journal of immunology. 2008; 181:6738-6746.

44. Ke Y, Sun D, Jiang G, Kaplan HJ and Shao H. PDL1(hi) retinal pigment epithelium (RPE) cells elicited by inflammatory cytokines induce regulatory activity in uveitogenic T cells. Journal of leukocyte biology. 2010; 88:1241-1249.

45. Seo SK, Seo DI, Park WS, Jung WK, Lee DS, Park SG, Choi JS, Kang MS, Choi YH, Choi I, Yu BC and Choi IW. Attenuation of IFN-gamma-induced B7-H1 expression by 15-deoxy-delta(12,14)-prostaglandin J2 via downregulation of the Jak/STAT/IRF-1 signaling pathway. Life sciences. 2014; 112:82-89.

46. Atefi M, Avramis E, Lassen A, Wong DJ, Robert L, Foulad D, Cerniglia M, Titz B, Chodon T, Graeber TG, CominAnduix B and Ribas A. Effects of MAPK and PI3K pathways on PD-L1 expression in melanoma. Clinical cancer research : an official journal of the American Association for Cancer Research. 2014; 20:3446-3457.

47. Marzec M, Zhang Q, Goradia A, Raghunath PN, Liu X, Paessler M, Wang HY, Wysocka M, Cheng M, Ruggeri BA and Wasik MA. Oncogenic kinase NPM/ALK induces through STAT3 expression of immunosuppressive protein CD274 (PD-L1, B7-H1). Proceedings of the National Academy of Sciences of the United States of America. 2008; 105:20852-20857.

48. Matta BM, Raimondi G, Rosborough BR, Sumpter TL and Thomson AW. IL-27 production and STAT3-dependent upregulation of B7-H1 mediate immune regulatory functions of liver plasmacytoid dendritic cells. Journal of immunology. 2012; 188:5227-5237.

49. Kaku $\mathrm{H}$ and Rothstein TL. Octamer binding protein 2 
(Oct2) regulates PD-L2 gene expression in B-1 cells through lineage-specific activity of a unique, intronic promoter. Genes and immunity. 2010; 11:55-66.

50. Radhakrishnan S, Nguyen LT, Ciric B, Van Keulen VP and Pease LR. B7-DC/PD-L2 cross-linking induces NFkappaB-dependent protection of dendritic cells from cell death. Journal of immunology. 2007; 178:1426-1432.

51. Li J, Jie HB, Lei Y, Gildener-Leapman N, Trivedi S, Green T, Kane LP and Ferris RL. PD-1/SHP-2 inhibits Tc1/Th1 phenotypic responses and the activation of $\mathrm{T}$ cells in the tumor microenvironment. Cancer research. 2015; 75:508518.

52. Liu X, Gibbons RM, Harrington SM, Krco CJ, Markovic $\mathrm{SN}$, Kwon ED and Dong H. Endogenous tumor-reactive CD8 T cells are differentiated effector cells expressing high levels of CD11a and PD-1 but are unable to control tumor growth. Oncoimmunology. 2013; 2:e23972.

53. Fourcade J, Sun Z, Pagliano O, Chauvin JM, Sander C, Janjic B, Tarhini AA, Tawbi HA, Kirkwood JM, Moschos S, Wang H, Guillaume P, Luescher IF, Krieg A, Anderson AC, Kuchroo VK, et al. PD-1 and Tim-3 regulate the expansion of tumor antigen-specific CD8(+) T cells induced by melanoma vaccines. Cancer research. 2014; 74:10451055.

54. Duraiswamy J, Kaluza KM, Freeman GJ and Coukos G. Dual blockade of PD-1 and CTLA-4 combined with tumor vaccine effectively restores $\mathrm{T}$-cell rejection function in tumors. Cancer research. 2013; 73:3591-3603.

55. Peng W, Liu C, Xu C, Lou Y, Chen J, Yang Y, Yagita H, Overwijk WW, Lizee G, Radvanyi L and Hwu P. PD-1 blockade enhances T-cell migration to tumors by elevating IFN-gamma inducible chemokines. Cancer research. 2012; 72:5209-5218.

56. Ahmadzadeh M, Johnson LA, Heemskerk B, Wunderlich JR, Dudley ME, White DE and Rosenberg SA. Tumor antigen-specific CD8 $\mathrm{T}$ cells infiltrating the tumor express high levels of PD-1 and are functionally impaired. Blood. 2009; 114:1537-1544.

57. Swaika A, Hammond WA and Joseph RW. Current state of anti-PD-L1 and anti-PD-1 agents in cancer therapy. Molecular immunology. 2015.

58. Ansell SM, Lesokhin AM, Borrello I, Halwani A, Scott EC, Gutierrez M, Schuster SJ, Millenson MM, Cattry D, Freeman GJ, Rodig SJ, Chapuy B, Ligon AH, Zhu L, Grosso JF, Kim SY, et al. PD-1 blockade with nivolumab in relapsed or refractory Hodgkin's lymphoma. The New England journal of medicine. 2015; 372:311-319.

59. Bishop JL, Sio A, Angeles A, Roberts ME, Azad AA, Chi $\mathrm{KN}$ and Zoubeidi A. PD-L1 is highly expressed in Enzalutamide resistant prostate cancer. Oncotarget. 2015; 6:234-242.

60. Feng Y, Shen J, Gao Y, Liao Y, Cote G, Choy E, Chebib I, Mankin H, Hornicek F and Duan Z. Expression of programmed cell death ligand 1 (PD-L1) and prevalence of tumor-infiltrating lymphocytes (TILs) in chordoma. Oncotarget. 2015; 6:11139-11149.

61. Iwai $\mathrm{Y}$, Ishida $\mathrm{M}$, Tanaka $\mathrm{Y}$, Okazaki $\mathrm{T}$, Honjo $\mathrm{T}$ and Minato N. Involvement of PD-L1 on tumor cells in the escape from host immune system and tumor immunotherapy by PD-L1 blockade. Proceedings of the National Academy of Sciences of the United States of America. 2002; 99:12293-12297.

62. Abiko K, Matsumura N, Hamanishi J, Horikawa N, Murakami R, Yamaguchi K, Yoshioka Y, Baba T, Konishi I and Mandai M. IFN-gamma from lymphocytes induces PDL1 expression and promotes progression of ovarian cancer. British journal of cancer. 2015; 112:1501-1509.

63. Jiang X, Zhou J, Giobbie-Hurder A, Wargo J and Hodi FS. The activation of MAPK in melanoma cells resistant to BRAF inhibition promotes PD-L1 expression that is reversible by MEK and PI3K inhibition. Clinical cancer research : an official journal of the American Association for Cancer Research. 2013; 19:598-609.

64. Brahmer JR, Drake CG, Wollner I, Powderly JD, Picus J, Sharfman WH, Stankevich E, Pons A, Salay TM, McMiller TL, Gilson MM, Wang C, Selby M, Taube JM, Anders R, Chen L, et al. Phase I study of single-agent anti-programmed death-1 (MDX-1106) in refractory solid tumors: safety, clinical activity, pharmacodynamics, and immunologic correlates. Journal of clinical oncology : official journal of the American Society of Clinical Oncology. 2010; 28:3167-3175.

65. Mamalis A, Garcha M and Jagdeo J. Targeting the PD-1 pathway: a promising future for the treatment of melanoma. Archives of dermatological research. 2014; 306:511-519.

66. Topalian SL, Sznol M, McDermott DF, Kluger HM, Carvajal RD, Sharfman WH, Brahmer JR, Lawrence DP, Atkins MB, Powderly JD, Leming PD, Lipson EJ, Puzanov I, Smith DC, Taube JM, Wigginton JM, et al. Survival, durable tumor remission, and long-term safety in patients with advanced melanoma receiving nivolumab. Journal of clinical oncology : official journal of the American Society of Clinical Oncology. 2014; 32:1020-1030.

67. Robert C, Long GV, Brady B, Dutriaux C, Maio M, Mortier L, Hassel JC, Rutkowski P, McNeil C, KalinkaWarzocha E, Savage KJ, Hernberg MM, Lebbe C, Charles J, Mihalcioiu C, Chiarion-Sileni V, et al. Nivolumab in previously untreated melanoma without BRAF mutation. The New England journal of medicine. 2015; 372:320-330.

68. Weber JS, D'Angelo SP, Minor D, Hodi FS, Gutzmer R, Neyns B, Hoeller C, Khushalani NI, Miller WH, Jr., Lao CD, Linette GP, Thomas L, Lorigan P, Grossmann KF, Hassel JC, Maio M, et al. Nivolumab versus chemotherapy in patients with advanced melanoma who progressed after anti-CTLA-4 treatment (CheckMate 037): a randomised, controlled, open-label, phase 3 trial. The Lancet Oncology. 2015; 16:375-384.

69. Belai EB, de Oliveira CE, Gasparoto TH, Ramos RN, Torres SA, Garlet GP, Cavassani KA, Silva JS and 
Campanelli AP. PD-1 blockage delays murine squamous cell carcinoma development. Carcinogenesis. 2014; 35:424431.

70. Gettinger SN, Horn L, Gandhi L, Spigel DR, Antonia SJ, Rizvi NA, Powderly JD, Heist RS, Carvajal RD, Jackman DM, Sequist LV, Smith DC, Leming P, Carbone DP, Pinder-Schenck MC, Topalian SL, et al. Overall Survival and Long-Term Safety of Nivolumab (Anti-Programmed Death 1 Antibody, BMS-936558, ONO-4538) in Patients With Previously Treated Advanced Non-Small-Cell Lung Cancer. Journal of clinical oncology : official journal of the American Society of Clinical Oncology. 2015; 33:20042012.

71. Rizvi NA, Mazieres J, Planchard D, Stinchcombe TE, Dy GK, Antonia SJ, Horn L, Lena H, Minenza E, Mennecier B, Otterson GA, Campos LT, Gandara DR, Levy BP, Nair SG, Zalcman G, et al. Activity and safety of nivolumab, an anti-PD-1 immune checkpoint inhibitor, for patients with advanced, refractory squamous non-small-cell lung cancer (CheckMate 063): a phase 2, single-arm trial. The Lancet Oncology. 2015; 16:257-265.

72. Thompson RH, Dong $H$ and Kwon ED. Implications of B7-H1 expression in clear cell carcinoma of the kidney for prognostication and therapy. Clinical cancer research : an official journal of the American Association for Cancer Research. 2007; 13:709s-715s.

73. McDermott DF, Drake CG, Sznol M, Choueiri TK, Powderly JD, Smith DC, Brahmer JR, Carvajal RD, Hammers HJ, Puzanov I, Hodi FS, Kluger HM, Topalian SL, Pardoll DM, Wigginton JM, Kollia GD, et al. Survival, Durable Response, and Long-Term Safety in Patients With Previously Treated Advanced Renal Cell Carcinoma Receiving Nivolumab. Journal of clinical oncology : official journal of the American Society of Clinical Oncology. 2015; 33:2013-2020.

74. Motzer RJ, Rini BI, McDermott DF, Redman BG, Kuzel TM, Harrison MR, Vaishampayan UN, Drabkin HA, George S, Logan TF, Margolin KA, Plimack ER, Lambert AM, Waxman IM and Hammers HJ. Nivolumab for Metastatic Renal Cell Carcinoma: Results of a Randomized Phase II Trial. Journal of clinical oncology : official journal of the American Society of Clinical Oncology. 2015; 33:1430-1437.

75. Robert C, Ribas A, Wolchok JD, Hodi FS, Hamid O, Kefford R, Weber JS, Joshua AM, Hwu WJ, Gangadhar TC, Patnaik A, Dronca R, Zarour H, Joseph RW, Boasberg $\mathrm{P}$, Chmielowski B, et al. Anti-programmed-death-receptor-1 treatment with pembrolizumab in ipilimumab-refractory advanced melanoma: a randomised dose-comparison cohort of a phase 1 trial. Lancet. 2014; 384:1109-1117.

76. Robert C, Schachter J, Long GV, Arance A, Grob JJ, Mortier L, Daud A, Carlino MS, McNeil C, Lotem M, Larkin J, Lorigan P, Neyns B, Blank CU, Hamid O, Mateus $\mathrm{C}$, et al. Pembrolizumab versus Ipilimumab in Advanced Melanoma. The New England journal of medicine. 2015;
372:2521-2532.

77. Garon EB, Rizvi NA, Hui R, Leighl N, Balmanoukian AS, Eder JP, Patnaik A, Aggarwal C, Gubens M, Horn L, Carcereny E, Ahn MJ, Felip E, Lee JS, Hellmann MD, Hamid O, et al. Pembrolizumab for the treatment of non-small-cell lung cancer. The New England journal of medicine. 2015; 372:2018-2028.

78. Hardy B, Morgenstern S, Raiter A, Rodionov G, Fadaeev L and Niv Y. BAT monoclonal antibody immunotherapy of human metastatic colorectal carcinoma in mice. Cancer letters. 2005; 229:217-222.

79. Berger R, Rotem-Yehudar R, Slama G, Landes S, Kneller A, Leiba M, Koren-Michowitz M, Shimoni A and Nagler A. Phase I safety and pharmacokinetic study of CT-011, a humanized antibody interacting with PD-1, in patients with advanced hematologic malignancies. Clinical cancer research : an official journal of the American Association for Cancer Research. 2008; 14:3044-3051.

80. Armand P, Nagler A, Weller EA, Devine SM, Avigan DE, Chen YB, Kaminski MS, Holland HK, Winter JN, Mason JR, Fay JW, Rizzieri DA, Hosing CM, Ball ED, Uberti JP, Lazarus HM, et al. Disabling immune tolerance by programmed death-1 blockade with pidilizumab after autologous hematopoietic stem-cell transplantation for diffuse large B-cell lymphoma: results of an international phase II trial. Journal of clinical oncology : official journal of the American Society of Clinical Oncology. 2013; 31:4199-4206.

81. Westin JR, Chu F, Zhang M, Fayad LE, Kwak LW, Fowler N, Romaguera J, Hagemeister F, Fanale M, Samaniego F, Feng L, Baladandayuthapani V, Wang Z, Ma W, Gao Y, Wallace M, et al. Safety and activity of PD1 blockade by pidilizumab in combination with rituximab in patients with relapsed follicular lymphoma: a single group, open-label, phase 2 trial. The Lancet Oncology. 2014; 15:69-77.

82. Powles T, Eder JP, Fine GD, Braiteh FS, Loriot Y, Cruz C, Bellmunt J, Burris HA, Petrylak DP, Teng SL, Shen X, Boyd Z, Hegde PS, Chen DS and Vogelzang NJ. MPDL3280A (anti-PD-L1) treatment leads to clinical activity in metastatic bladder cancer. Nature. 2014; 515:558-562.

83. Lee SM and Chow LQ. A new addition to the PD-1 checkpoint inhibitors for non-small cell lung cancer-the anti-PDL1 antibody-MEDI4736. Translational lung cancer research. 2014; 3:408-410.

84. Tang Y, Fang W, Zhang Y, Hong S, Kang S, Yan Y, Chen N, Zhan J, He X, Qin T, Li G, Tang W, Peng P and Zhang L. The association between PD-L1 and EGFR status and the prognostic value of PD-L1 in advanced non-small cell lung cancer patients treated with EGFR-TKIs. Oncotarget. 2015; 6:14209-14219.

85. Akbay EA, Koyama S, Carretero J, Altabef A, Tchaicha JH, Christensen CL, Mikse OR, Cherniack AD, Beauchamp EM, Pugh TJ, Wilkerson MD, Fecci PE, Butaney M, Reibel JB, Soucheray M, Cohoon TJ, et al. Activation of the PD-1 
pathway contributes to immune escape in EGFR-driven lung tumors. Cancer discovery. 2013; 3:1355-1363.

86. Rizvi NA, Hellmann MD, Snyder A, Kvistborg P, Makarov V, Havel JJ, Lee W, Yuan J, Wong P, Ho TS, Miller ML, Rekhtman N, Moreira AL, Ibrahim F, Bruggeman C, Gasmi B, et al. Cancer immunology. Mutational landscape determines sensitivity to PD-1 blockade in non-small cell lung cancer. Science. 2015; 348:124-128.

87. Van Allen EM, Golay HG, Liu Y, Koyama S, Wong K, Taylor-Weiner A, Giannakis M, Harden M, Rojas-Rudilla V, Chevalier A, Thai T, Lydon C, Mach S, Avila AG, Wong JA, Rabin AR, et al. Long-term Benefit of PD-L1 Blockade in Lung Cancer Associated with JAK3 Activation. Cancer immunology research. 2015.

88. Merelli B, Massi D, Cattaneo L and Mandala M. Targeting the PD1/PD-L1 axis in melanoma: biological rationale, clinical challenges and opportunities. Critical reviews in oncology/hematology. 2014; 89:140-165.

89. Carbognin L, Pilotto S, Milella M, Vaccaro V, Brunelli M, Calio A, Cuppone F, Sperduti I, Giannarelli D, Chilosi M, Bronte V, Scarpa A, Bria E and Tortora G. Differential Activity of Nivolumab, Pembrolizumab and MPDL3280A according to the Tumor Expression of Programmed Death-Ligand-1 (PD-L1): Sensitivity Analysis of Trials in Melanoma, Lung and Genitourinary Cancers. PloS one. 2015; 10:e130142.

90. Rodic N, Anders RA, Eshleman JR, Lin MT, Xu H, Kim JH, Beierl K, Chen S, Luber BS, Wang H, Topalian SL, Pardoll DM and Taube JM. PD-L1 expression in melanocytic lesions does not correlate with the BRAF V600E mutation. Cancer immunology research. 2015; 3:110-115.

91. Yang CY, Lin MW, Chang YL, Wu CT and Yang PC. Programmed cell death-ligand 1 expression in surgically resected stage I pulmonary adenocarcinoma and its correlation with driver mutations and clinical outcomes. European journal of cancer. 2014; 50:1361-1369.

92. Johnson DB, Lovly CM, Flavin M, Panageas KS, Ayers GD, Zhao Z, Iams WT, Colgan M, DeNoble S, Terry CR, Berry EG, Iafrate AJ, Sullivan RJ, Carvajal RD and Sosman JA. Impact of NRAS mutations for patients with advanced melanoma treated with immune therapies. Cancer immunology research. 2015; 3:288-295.

93. Schalper KA, Velcheti V, Carvajal D, Wimberly H, Brown J, Pusztai L and Rimm DL. In situ tumor PD-L1 mRNA expression is associated with increased TILs and better outcome in breast carcinomas. Clinical cancer research : an official journal of the American Association for Cancer Research. 2014; 20:2773-2782.

94. Herbst RS, Soria JC, Kowanetz M, Fine GD, Hamid O, Gordon MS, Sosman JA, McDermott DF, Powderly JD, Gettinger SN, Kohrt HE, Horn L, Lawrence DP, Rost S, Leabman M, Xiao Y, et al. Predictive correlates of response to the anti-PD-L1 antibody MPDL3280A in cancer patients. Nature. 2014; 515:563-567.

95. Tumeh PC, Harview CL, Yearley JH, Shintaku IP, Taylor
EJ, Robert L, Chmielowski B, Spasic M, Henry G, Ciobanu V, West AN, Carmona M, Kivork C, Seja E, Cherry G, Gutierrez AJ, et al. PD-1 blockade induces responses by inhibiting adaptive immune resistance. Nature. 2014; 515:568-571.

96. Le DT, Uram JN, Wang H, Bartlett BR, Kemberling $\mathrm{H}$, Eyring AD, Skora AD, Luber BS, Azad NS, Laheru D, Biedrzycki B, Donehower RC, Zaheer A, Fisher GA, Crocenzi TS, Lee JJ, et al. PD-1 Blockade in Tumors with Mismatch-Repair Deficiency. The New England journal of medicine. 2015; 372:2509-2520. 